\title{
CHARACTERISTICS OF Bromus cartharticus Vahl (Poaceae) NATURAL POPULATIONS COLLECTED IN THE CENTRAL AREA OF ARGENTINA
}

\author{
Beatriz Rosso ${ }^{1 *}$; Elba Pagano²; Pedro Rimieri'; Raúl Ríos² \\ ${ }_{2}^{1}$ EEA.- INTA, c.c. 31, Pergamino-2700, Argentina. \\ ${ }^{2}$ Instituto de Genética "Edwald A. Favret", CICVyA, INTA. C.C. 25-1712. Castelar, Argentina \\ *Corresponding author <brosso@pergamino.inta.gov.ar>
}

\begin{abstract}
Collection of Bromus catharticus Vahl was carried out in the Argentine humid and subhumid central area. Sixty-eight natural populations are conserved for medium and long term in Pergamino Germplasm Bank and in IRB Germplasm Bank, and ten morphological and agronomic traits were evaluated in the field during two years. There was variability for the traits considered among the accessions. Those populations from the subhumid area showed differences in valuable attributes for breeding. Exploration of marginal areas for this species might be an effective way to add variability to this collection.

Key words: evaluation, germplasm, prairie grass, plant breeding
\end{abstract}

\section{CARACTERÍSTICAS DE POPULAÇÕES NATURAIS DE Bromus cartharticus Vahl (Poaceae) COLETADAS NA ÁREA CENTRAL DA ARGENTINA}

\begin{abstract}
RESUMO: Coletas de Bromus catharticus Vahl foram conduzidas nas areas úmidas e sub-úmidas centrais da Argentina. Sessenta e oito populações naturais foram mantidas por médio e longo períodos nos bancos de germoplasma Pergamino e IRB, e dez características morfológicas agronômicas foram avaliadas em campo durante dois anos. Foi observada variabilidade para as características entre os acessos. As populações da região sub-úmida mostraram diferenças para características importantes para o melhoramento. A exploração de áreas marginais para esta espécie pode ser um modo efetivo de adicionar variabilidade para esta coleção de germoplasma.

Palavras-chave: avaliação, germoplasma, capim de pradaria, melhoramento de plantas
\end{abstract}

\section{INTRODUCTION}

Beef production systems in Argentina are mainly based on direct grazing of grassland and pasture (Rearte, 1998). The grasslands in the Argentina Pampean region are polyphytic systems formed by native and naturalized plant species. Some native species are key components of cultivated pastures due to the total or seasonal forage production, forage quality and/ or tolerance to diverse environmental conditions. Among these, Bromus catharticus Vahl (family Poaceae, subfamily Festucoidea, tribe Festucea; synm. Bromus unioloides H.B.K.; Bromus wildenowii Kunth) is considered the most important forage grass in terms of the amount of certified seed production in Argentina.

The centre of origin of this species is the humid region of the Pampas meadowland, and it reaches also to Uruguay, the south of Brazil and the north cen- tral area of Chile. It is commonly known as cebadilla criolla, cebadilla australiana, rescue grass (U.S.A) and prairie grass (New Zealand). It is hexaploid with a basic chromosome number of $\mathrm{x}=7$ (Naranjo, 1985). Although it produces either chasmogamous or cleistogamous flowers according to the phase of the flowering cycle, its reproductive behaviour corresponds to that of an autogamus species. Thus, the natural outcrossing rate during the chasmogamous phase was estimated in 1.8\% (Morant et al., 1994). Despite the commercial importance of this species, there are very few cultivars available in the market and, according to Puecher et al. (2001) they had a narrow genetic base. There are few collections of this species reported in Argentina (Massa et al., 1997; Rosso, 2001). Morphological traits were used to characterize populations. However, just a small number of populations or populations from a narrow range of climatic conditions 
were analyzed (Szpiniak et al., 1995; Aulicino \& Arturi, 2002; Wolff et al., 1996; Pistorale et al., 1999).

With the objective of conserving and studying natural populations of $B$. catharticus as to their possible value for breeding, samples were collected in the Argentine central area and they were preliminarily evaluated at Pergamino EEA-INTA station.

\section{MATERIAL AND METHODS}

\section{Collection}

A strip of land confined between latitudes $30^{\circ} 23^{\prime} \mathrm{S}$ to $37^{\circ} 21^{\prime} \mathrm{S}$, and between $58^{\circ} 47^{\prime} \mathrm{W}$ to $65^{\circ} 38^{\prime}$ $\mathrm{W}$ longitude (Figure 1), was covered during November 1998, November 1999 and November 2000. The area included the provinces of Buenos Aires, Santa Fe, Entre Rios, Córdoba, La Pampa and San Luis. The altitude of the visited area ranged from 5 to $994 \mathrm{~m}$, the annual mean temperature from $15^{\circ} \mathrm{C}$ to $18^{\circ} \mathrm{C}$, and the annual precipitation from 440 to $1072 \mathrm{~mm}$. The west part of the visited area is considered subhumid (below $700 \mathrm{~mm}$ ) with frequent shortfall of soil moisture.

In 68 nondisturbed sites, mass sampling was carried out from approximately 100 randomly chosen plants of each population (Hawkes, 1976), and a panicle per plant was harvested. Panicles were allowed to dry and then were cropped at the EEA INTA. Seeds were cleaned and dried to around 5\% moisture content and packed in waterproof envelopes and conserved in storeroom at $7^{\circ} \mathrm{C}$ at the Pergamino Active

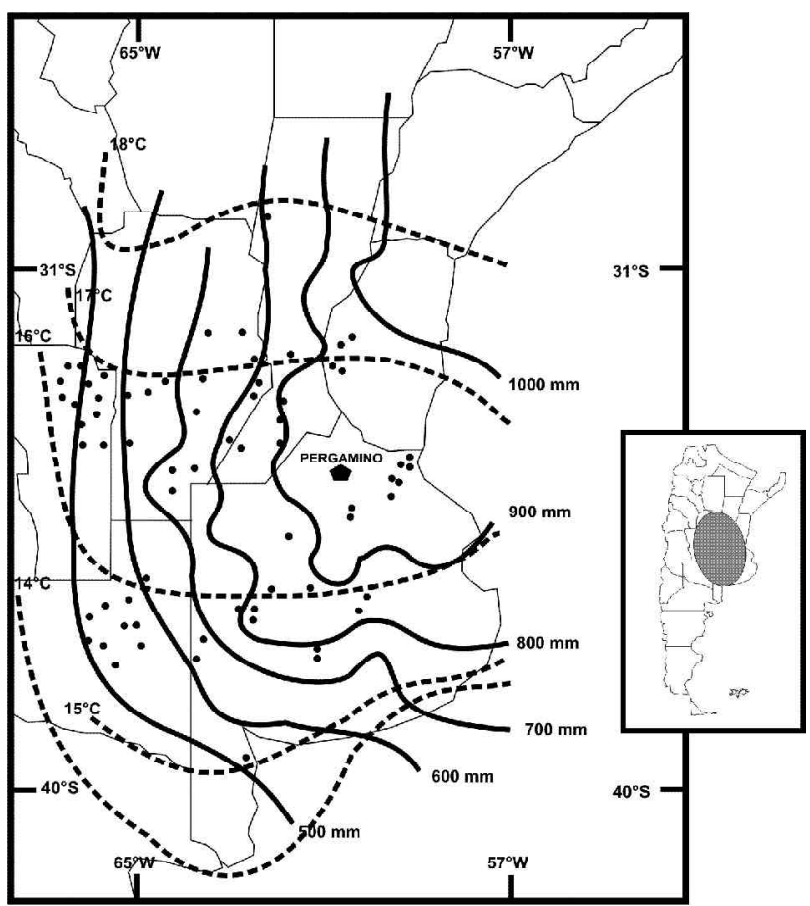

Figure 1 - Area visited during the collection of Bromus catharticus Vahl.
Bank. One copy of the collection is located in the Base Bank stored at $-20^{\circ} \mathrm{C}$.

\section{Field evaluation}

Material was sown in a greenhouse in April 2001 and transplanted to single rows in the field at the end of May 2001. During 2001 and 2002, twenty plants of each population were evaluated on the experimental fields of Pergamino EEA-INTA (335' S, 60³' W). The control population was an Argentine cultivar (Martín Fierro MAG) released in 1952.

The characters scored or measured were: number of winter vegetative tillers, vegetative growth habit $(1=$ prostrate, $9=$ erect $)$, winter forage production $(1=$ low, $9=$ high $)$, length and width of vegetative leaf $(\mathrm{cm})$, days to $50 \%$ flowering (from September $1^{\text {st }}$ ), height at flowering $(\mathrm{cm})$, panicles/plant (number), seed yield $(\mathrm{g}) / \mathrm{plant}$, and persistence $(\%)$.

Data were analyzed using the statistical software package SAS Institute (1999). Single correlations analysis was carried out and significance was determined. The morphological data were analyzed by Principal Component Analysis (PCA) with previous standardization in order to generate a mean of zero and a variance of one, and consequently remove scaling effects. Principal Components whose eigenvalues were higher than two are presented.

\section{RESULTS AND DISCUSSION}

Sixty-eight natural Argentine populations of rescue grass were collected, and conserved with at least 3000 seeds per accession. A broad range of agroecological conditions was covered in this collection, including the area known as humid and subhumid Pampas. Seed maturity was reached earlier in the northern part of the area collected. The beginning of November was considered the optimum time for the obtaining maximum number of seeds per plant, before shedding becomes too severe.

When comparing the germplasm collection with the control cultivar, accessions that outranged the bred population were observed (Table 1). This is true in variables such as number of vegetative tillers and percentage of surviving plants, which could be useful to increasing forage yield and plant persistence of new cultivars. The lower rank observed for persistence was similar to that of the check cultivar, and there were 10 natural populations with survivorship rates higher than $80 \%$ of the plants at the end of the second year. According to Scheneiter \& Rosso (2005), there are differences in tiller dynamics and persistence among prairie grass germplasm that could be used in breeding programs. 
There were very few significant correlations among variables (Table 2). Winter forage production did correlate with seed yield suggesting that increasing forage and seed yield at the same time is possible.
In Figure 2, populations collected in the humid and subhumid area are distributed so as to form two overlapping groups on a Principal Component (PC) graph showing first and second components. Characters that

Table 1 - Means values, standard deviations and ranges of variation for each trait in 68 natural populations of Bromus catharticus Vahl. Mean values of the control cultivar Martín Fierro MAG.

\begin{tabular}{lccc}
\hline Attribute & Mean and standard error & Range & Martin Fierro MAG \\
\hline Number of winter vegetative tillers & $10.6 \pm 2.8$ & $5-19$ & 5 \\
Vegetative growth habit $(1=$ prostrate, $9=$ erect) & $5.2 \pm 1.1$ & $3-8$ & 7 \\
Length of vegetative leaf $(\mathrm{cm})$ & $30.6 \pm 3.3$ & $22.2-38.8$ & 32.7 \\
Width of vegetative leaf $(\mathrm{cm})$ & $1.1 \pm 0.12$ & $0.6-1.3$ & 1.4 \\
Winter forage production $(1=$ low, $9=$ high) & $5.7 \pm 1.5$ & $3-9$ & 7 \\
Days to 50\% flowering (from September $\left.1^{\text {st }}\right)$ & $47 \pm 6.5$ & $32-62$ & 47 \\
Height at flowering $(\mathrm{cm})$ & $138.2 \pm 12.8$ & $95-160$ & 155 \\
Panicles/plant & $15.2 \pm 4.6$ & $8-32.3$ & 12 \\
Seed yield $(\mathrm{g}) /$ plant & $19.7 \pm 6.4$ & $10.4-52$ & 19.9 \\
Persistence $(\%)$ & $89.4 \pm 10.9$ & $46.2-100$ & 45 \\
\hline
\end{tabular}

Table 2 - The phenotypic correlation coefficients between 10 characters in 68 rescue grass populations.

\begin{tabular}{|c|c|c|c|}
\hline & Height at flowering & Persistence & Seed yield \\
\hline Number of winter vegetative tillers & $-0.21 * *$ & & \\
\hline Width of vegetative leaf & & $0.35 *$ & \\
\hline Length of vegetative leaf & & & $0.25 * *$ \\
\hline Height at flowering & & & $0.23 *$ \\
\hline Panicles/plant & & & $0.63 * *$ \\
\hline Winter forage production & & & $0.58 * *$ \\
\hline
\end{tabular}

*Significance $5 \% * *$ significance $1 \%$. Empty cells $=$ no significant correlation.

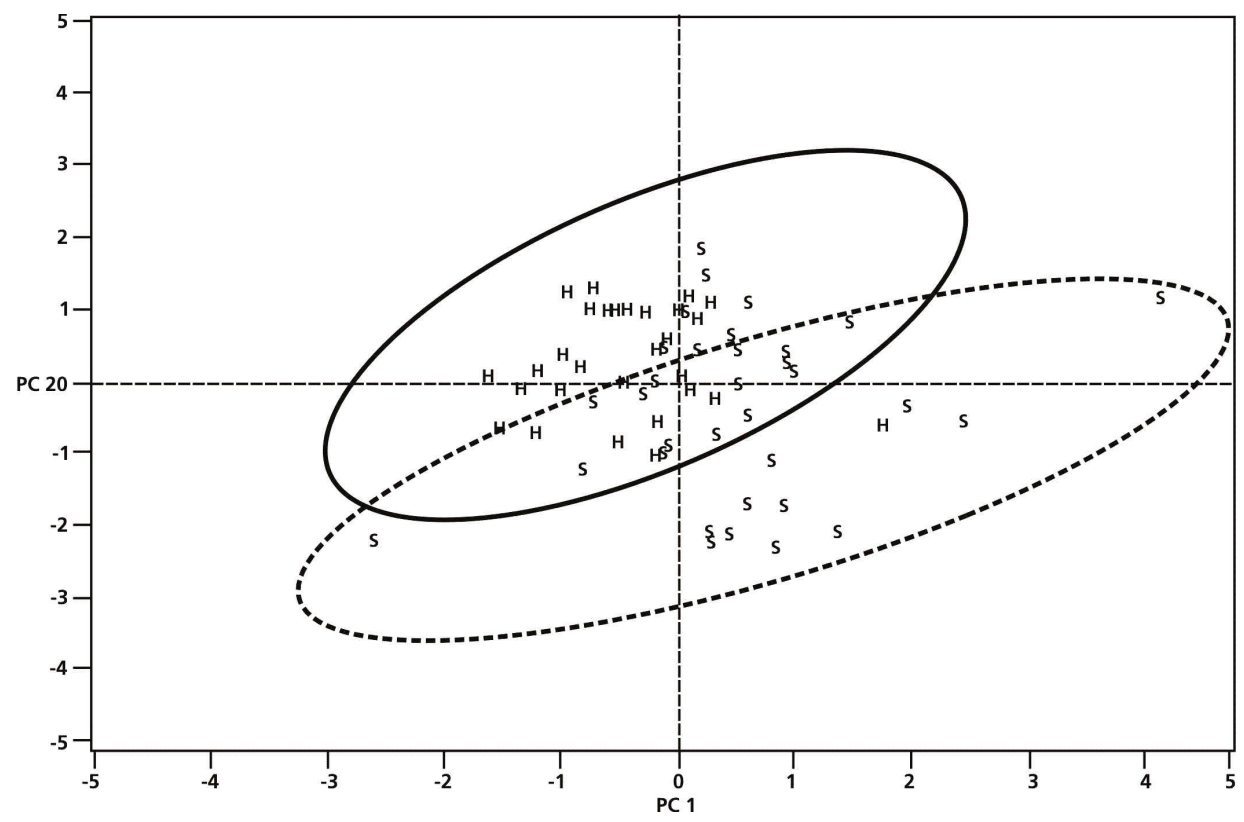

Figure 2 - Coordinates on the first and second principal component axes (PC1 and PC2). PC1 and PC2 represent 21\% and 20\% of the total variation respectively. $\mathrm{H}=$ populations from the humid area, $\mathrm{S}=$ populations from the subhumid area 
contributed the larger weights were winter forage production, number of panicles/plant and seed yield $(\mathrm{g}) /$ plant (PC 1). Higher phenotypic diversity for PC1 was from populations from the subhumid area. Width of vegetative leaf and height at flowering explained most of the variation in PC 2. Characters related to forage production and persistence that could be incorporated in bred populations received special interest. Those characteristics were mostly found in populations collected in areas considered marginal for this species. Following the suggestion of Puecher et al. (2001), rescue grass breeding programs in Argentina should utilize these germplasm because variability of cultivars has a narrow range and the way to overcome this deficiency would be exploring native populations.

The inclusion of populations from the subhumid area increased the phenotypic diversity of the germplasm collection and might be helpful for the adaptation to stressful environments in new cultivars.

\section{ACKNOWLEDGEMENTS}

To E. Maiola for his support in translating the manuscript.

\section{REFERENCES}

AULICINO, M.; ARTURI, M. Phenotypic diversity in Argentinian populations of Bromus catharticus (Poaceae): genetic and environmental components of quantitative traits. New Zealand Journal of Botany. v.40, p.223-234, 2002

HAWKES, J.G. Germplasm collection: manual for field collectors. Rome: FAO, 1976. 33p.

MASSA, A.; ZAPPE, A.H.; GANDULLO, R.; ACUÑA H.; SEGUEL, I. Collecting Bromus L. in the Patagonian Andes. Plant Genetic Resources Newsletter, v.110, p.1-4, 1997
MORANT, A.; PAHLEN, A. von der; CLADERA, J.; SERRANO, $H$. Determinación del porcentaje de fecundación cruzada en cebadilla criolla (Bromus catharticus Vahl.). Pergamino: EEA-INTA, 1994. 23p. (Informe Técnico, 291).

NARANJO, C. Estudios citogenéticos, bioquímicos y sistemáticos en algunas especies americanas del género Bromus. Buenos Aires: Universidad de Buenos Aires/ Facultad de Ciencias Exactas y Naturales, 1985. 243p. (Doctorado).

PISTORALE, S.; WOLF, R.; BAZZIGALUPI, O.. Dormancy and seed germination in natural populations of Bromus catharticus Vahl (Cebadilla criolla). Journal of Genetics and Breeding. v.53, p.47-55, 1999.

PUECHER, D.I.; ROBREDO, C.G.; RIOS, R.D.; RIMIERI, P. Genetic variability measures among Bromus catharticus Vahl. populations and cultivars with RAPD and AFLP markers. Euphytica, v.121, p.229-236, 2001.

REARTE, D.H. Beef cattle production and meat quality on grazing system in temperate regions. Revista Argentina de Producción Animal, v.18, p.120-142, 1998.

ROSSO, B. Colecta y caracterización de cebadilla criolla (Bromus catharticus Vahl.) en la región central de Argentina. In: Diálogo LVI, los recursos fitogenéticos del género Bromus en el Cono Sur. Montevideo: PROCISUR, 2001. p.99-101.

SAS INSTITUTE. The SAS system: version 8. Cary: SAS Institute, 1999. 752p.

SCHENEITER, O.; ROSSO, B. Herbage accumulation and tiller dynamics of prairie grass Germplasm (Bromus catharticus Vhal.) in mixture with Lucerne (Medicago sativa L.). Revista de Investigaciones Agropecuarias, v.34, p.109-121, 2005.

SZPINIAK, B.; FERREIRA, V.; SEPLIARSKY, A.; IRICO, M. Análisis de la variación de Bromus catharticus Vahl. en ambientes subhúmedos-secos de la República Argentina con fines de mejoramiento. Mendeliana, v.11, p.84-98, 1995.

WOLFF, R.; ABBOTT, L.; PISTORALE, S. Reproduction behaviour of Bromus catharticus Vahl (Cebadilla criolla) in natural and cultivated populations. Journal of Genetics and Breeding, v.50, p.122-128, 1996.

Received August 31, 2007

Accepted August 14, 2008 